Article

\title{
Petromylidenes A-C: 2-Alkylidene Bile Salt Derivatives Isolated from Sea Lamprey (Petromyzon marinus)
}

\author{
Ke Li, Anne M. Scott, Skye D. Fissette, Tyler J. Buchinger, Joseph J. Riedy and Weiming Li * \\ Department of Fisheries and Wildlife, Michigan State University, East Lansing, MI 48824, USA; \\ like4@msu.edu (K.L.); Scottan7@msu.edu (A.M.S.); fissette@msu.edu (S.D.F.); buching6@msu.edu (T.J.B.); \\ riedyjos@msu.edu (J.J.R.) \\ * Correspondence: liweim@msu.edu; Tel.: +1-517-432-6705
}

Received: 9 August 2018; Accepted: 29 August 2018; Published: 1 September 2018

\begin{abstract}
Three novel bile acid derivatives, petromylidenes A-C (1-3), featuring uncommon alkylidene adductive scaffolds, were isolated from water conditioned with sexually mature male sea lampreys (Petromyzon marinus). Their structures were elucidated by mass spectrometry and NMR spectroscopy, and by comparison to spectral data of related structures. The identification of compounds 1-3, further illustrates the structural diversity of the $5 \alpha$ bile salt family. Compounds 1-3 exhibited notable biological properties as well, including high olfactory potencies in adult sea lampreys and strong behavioral attraction of ovulated female sea lampreys. Electro-olfactogram recordings indicated that the limit of detection for $\mathbf{1}$ was $10^{-9} \mathrm{M}, \mathbf{2}$ was $10^{-11} \mathrm{M}$, and 3 was less than $10^{-13} \mathrm{M}$. These results suggested 1-3 were likely male pheromones, which guide reproductive behaviors in the sea lamprey.
\end{abstract}

Keywords: bile salts; pheromone; electro-olfactogram; behavioral assay; invasive species; cyclostomata

\section{Introduction}

The sea lamprey is an invasive, parasitic vertebrate in the Laurentian Great Lakes. One emerging option to control the invasive sea lamprey population is the application of the pheromones, to modulate reproductive behaviors in this species [1]. Investigations of pheromone communication in sea lamprey have unveiled that sea lampreys, similar to many other fishes, have an olfactory system which is acutely sensitive to bile salts [2,3]. Furthermore, spermiated male lampreys (sexually mature males with expressible milt) produce unique sulfated bile alcohols with a C24 backbone and $5 \alpha$ configuration, which aggregate potential mates during spawning [4-8]. In our ongoing investigation for structurally diverse and biologically active compounds released from spawning male sea lampreys, we identified three novel bile salts trivially named petromylidenes A-C (1-3, Figure 1), and a known compound 3-keto petromyzonol sulfate, 3kPZS (4, Figure 1). Petromylidenes A-C (1-3) possess the same steroid framework as the main compound already described 3kPZS (4) but differ from each other in the nature of the alkylidene substituent at C-2. The double bond geometry in the alkylidene moiety was assigned as $E$ in $\mathbf{1}$ and 3, whereas $\mathbf{2}$ was a mixture of both $E$ and $Z$ isomers. Here, we describe their isolation from water conditioned with spermiated male sea lampreys, structure elucidation, and biological activity assays. 


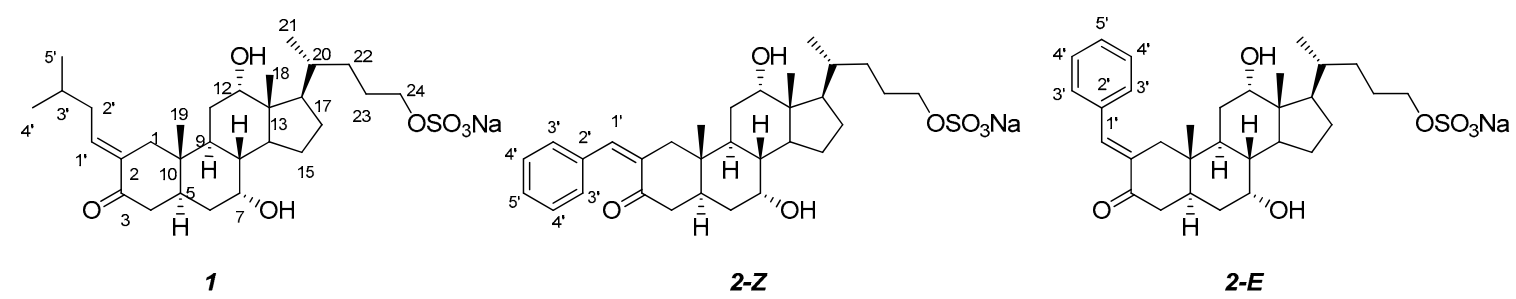

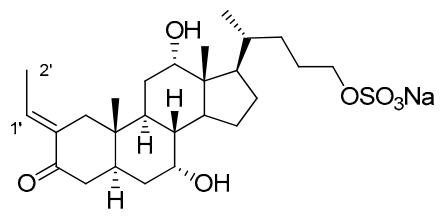

3

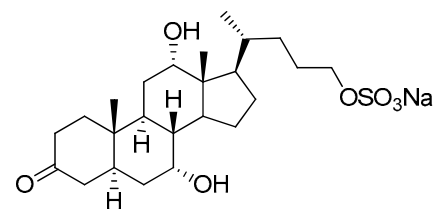

4

Figure 1. Structures of petromylidenes A (1), B (2), C (3), and 3kPZS (4).

\section{Results and Discussion}

Petromylidene A (1) was obtained as a yellowish oil with $[\alpha]_{\mathrm{D}}^{25}+6.6(\mathrm{c} 0.10, \mathrm{MeOH})$ and has the molecular formula $\mathrm{C}_{29} \mathrm{H}_{48} \mathrm{O}_{7} \mathrm{~S}$ as established by HRESIMS $\left(\mathrm{m} / z 539.3058[\mathrm{M}-\mathrm{H}]^{-}\right)$, which indicated six degrees of unsaturation. The ${ }^{1} \mathrm{H}$ and ${ }^{13} \mathrm{C}$ NMR spectra (Supplementary Materials Figures S1 and S2) revealed that 1 has a close resemblance to 3kPZS (4) [9], and further confirmed a minor modification on ring A. Analysis of the multiplicities and the vicinal $J$ values of the two carbinol methine protons in the ${ }^{1} \mathrm{H}$ NMR spectrum (Table 1), allowed us to assign an equatorially-oriented plane to C-7 and C-12. Axial hydroxyl groups placed at C-7 and C-12 are consistent with the substitution pattern of sulfated steroids, established by Hoye et al. [10]. The remaining subunit $\mathrm{C}_{5} \mathrm{H}_{10}$ was assigned as 3-methylbutyl, based on the COSY and HMBC correlations (Figure 2). The connectivity between 3-methylbutyl and $3 \mathrm{kPZS}$ (4) skeleton at C-2, with a double bond, was supported by HMBC correlations (Figure 2) from $\mathrm{H}-1^{\prime}$ to $\mathrm{C}-1$ and $\mathrm{C}-3$, and from $\mathrm{H}-1$ to $\mathrm{C}-1^{\prime}$. The presence of the double bond was indicated by the chemical shifts of $\mathrm{CH}-1^{\prime}\left(\delta_{\mathrm{C}} 141.8, \delta_{\mathrm{H}} 6.68\right)$ and $\mathrm{C}-2\left(\delta_{\mathrm{C}} 137.3\right)$. The planar structure of 1 can be assigned as 2-(3-methylbutylidene)-3kPZS.
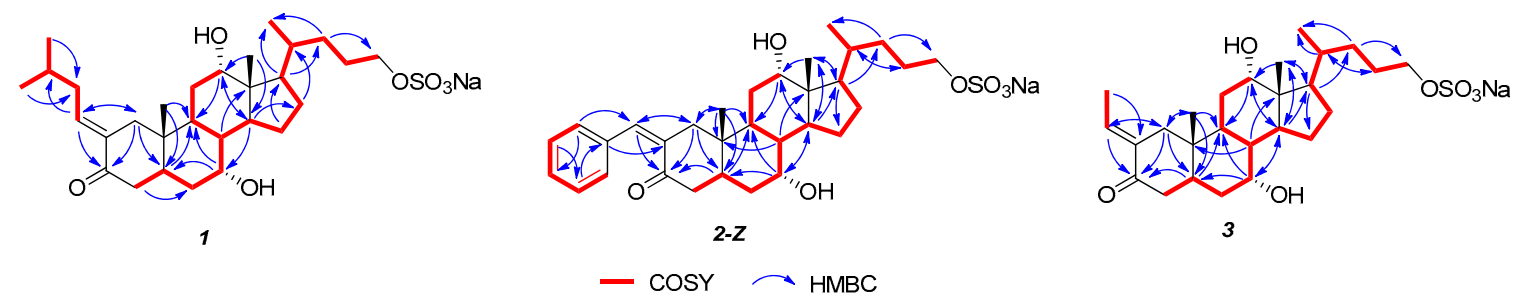

Figure 2. Key COSY and HMBC correlations of petromylidenes A-C (1-3).

The NOESY key correlations of 1 (Supplementary Materials Figure S9) from $\mathrm{H}_{3}-19 / \mathrm{H}-8$; $\mathrm{H}-8 / \mathrm{H}_{3}-18$; and $\mathrm{H}_{3}-18 / \mathrm{H}-20$ indicated that $\mathrm{CH}_{3}-18$ and $\mathrm{CH}_{3}-19$ were on the $\beta$ face, confirming the stereochemistry of the steroidal skeleton. In addition, the correlations from $\mathrm{H}-5 / \mathrm{H}-14, \mathrm{H}-14 / \mathrm{H}-17$ supported the orientation of $\mathrm{H}-5$ and $\mathrm{H}-14$ on the $\alpha$ face (Figure 3). The stereochemistry of double bond between $\mathrm{C}-1^{\prime}$ and $\mathrm{C}-2$ was assigned by comparison of the chemical shift values of $\mathrm{H}-1^{\prime}$ with that of the $E$ and $Z$ double bond, of the model compounds. In the ${ }^{1} \mathrm{H}$ NMR spectrum of $\mathbf{1}$, the olefinic proton resonated at $\delta_{\mathrm{H}}$ 6.68. The olefinic protons in $E$ and $Z$ configurations of analogs, yielded characteristic signals at $\delta 6.62$ and 5.60, respectively [11-13]. The proton resonance of 1 was in good agreement with that of $E$ configuration. These values were supportive of the stereochemical assignments of $E$ configuration, for the double bond located on C-2. Thus, the structure of $\mathbf{1}$ was 
assigned as 2-(E)-(3-methylbutylidene)-7 $\alpha, 12 \alpha, 24$-trihydroxy-5 $\alpha$-cholan-3-one-24-sulfate and trivially named petromylidene $\mathrm{A}$.

Table 1. NMR Spectroscopic Data (900 and $225 \mathrm{MHz}, \mathrm{MeOD})$ for petromylidenes A, B, and C (1-3).

\begin{tabular}{|c|c|c|c|c|c|c|}
\hline \multirow{2}{*}{ No } & \multicolumn{2}{|c|}{ Petromylidene A (1) } & \multicolumn{2}{|c|}{ Petromylidene B (2) } & \multicolumn{2}{|c|}{ Petromylidene C (3) } \\
\hline & $\delta_{\mathrm{H}}(J$ in $\mathrm{Hz})$ & $\delta_{\mathrm{C}}$, Type & $\delta_{\mathrm{H}}(J$ in $\mathrm{Hz})$ & $\delta_{\mathrm{C}}$, Type & $\delta_{\mathrm{H}}(J$ in $\mathrm{Hz})$ & $\delta_{\mathrm{C}}$, Type \\
\hline $1 \alpha$ & $1.93, \mathrm{~d}(16.1)$ & $40.9, \mathrm{CH}_{2}$ & $2.28, \mathrm{~m}$ & $51.3, \mathrm{CH}_{2}$ & $1.95, \mathrm{~d}(15.6)$ & $40.5, \mathrm{CH}_{2}$ \\
\hline $1 \beta$ & 2.77, d (16.1) & & $2.64, \mathrm{~d}(13.6)$ & & 2.77, d (15.4) & \\
\hline 2 & & 137.3, C & & $140.4, C$ & & $137.6, \mathrm{C}$ \\
\hline 3 & & $203.4, C$ & & $207.7, \mathrm{C}$ & & 203.2, C \\
\hline $4 \alpha$ & $2.15, \mathrm{~m}$ & $43.6, \mathrm{CH}_{2}$ & 2.18, dd $(14.9,4.1)$ & $47.6, \mathrm{CH}_{2}$ & $2.15, \mathrm{~m}$ & $43.5, \mathrm{CH}_{2}$ \\
\hline $4 \beta$ & $2.22, \mathrm{~m}$ & & $2.52, \mathrm{~m}$ & & $2.22, \mathrm{~m}$ & \\
\hline 5 & $2.22, \mathrm{~m}$ & $37.0, \mathrm{CH}$ & 2.27, m & $41.1, \mathrm{CH}$ & $2.22, \mathrm{~m}$ & $37.0, \mathrm{CH}$ \\
\hline $6 \alpha$ & 1.47, m & $37.5, \mathrm{CH}_{2}$ & $1.52, \mathrm{~m}$ & $37.7, \mathrm{CH}_{2}$ & $1.47, \mathrm{~m}$ & $37.5, \mathrm{CH}_{2}$ \\
\hline $6 \beta$ & $1.55, \mathrm{~m}$ & & $1.58, \mathrm{~m}$ & & $1.55, \mathrm{~m}$ & \\
\hline $7 \beta$ & 3.81, ddd $(7.8,2.6,2.6)$ & $68.1, \mathrm{CH}$ & $3.80, \mathrm{dd}(2.5,5.3)$ & $68.3, \mathrm{CH}$ & 3.81 , ddd $(2.5,5.2)$ & $68.1, \mathrm{CH}$ \\
\hline $8 \beta$ & $1.46, \mathrm{~m}$ & $41.3, \mathrm{CH}$ & $1.49, \mathrm{~m}$ & $41.4, \mathrm{CH}$ & $1.46, \mathrm{~m}$ & $41.4, \mathrm{CH}$ \\
\hline $9 \alpha$ & $1.82, \operatorname{ddd}(12.5,4.6,2.0)$ & $39.6, \mathrm{CH}$ & $1.82, \mathrm{~m}$ & $39.8, \mathrm{CH}$ & $1.83, \mathrm{~m}$ & $39.7, \mathrm{CH}$ \\
\hline 10 & & $36.5, \mathrm{C}$ & & $39.2, \mathrm{C}$ & & $36.4, \mathrm{C}$ \\
\hline $11 \alpha$ & $1.68, \mathrm{~m}$ & $29.8, \mathrm{CH}_{2}$ & $1.72, \mathrm{~m}$ & $30.2, \mathrm{CH}_{2}$ & $1.70, \mathrm{~m}$ & $30.0, \mathrm{CH}_{2}$ \\
\hline $11 \beta$ & $1.72, \mathrm{~m}$ & & & & & \\
\hline 12 & $4.00, \mathrm{dd}(2.6,2.6)$ & $73.9, \mathrm{CH}$ & $4.01, \mathrm{dd}(2.9,2.9)$ & $73.9, \mathrm{CH}$ & $4.02, \mathrm{dd}(2.6,2.6)$ & $73.9, \mathrm{CH}$ \\
\hline 13 & & $47.6, \mathrm{C}$ & & $47.7, \mathrm{C}$ & & $47.6, \mathrm{C}$ \\
\hline $14 \alpha$ & 1.99, ddd $(7.5,12.0,12.2)$ & $43.2, \mathrm{CH}$ & 2.00, ddd $(7.6,12.0,12.2)$ & $43.2, \mathrm{CH}$ & 1.99, ddd $(7.5,12.0,12.2)$ & $43.2, \mathrm{CH}$ \\
\hline $15 \alpha$ & $1.13, \mathrm{~m}$ & $24.3, \mathrm{CH}_{2}$ & $1.13, \mathrm{~m}$ & $24.3, \mathrm{CH}_{2}$ & $1.14, \mathrm{~m}$ & $24.3, \mathrm{CH}_{2}$ \\
\hline $15 \beta$ & $1.78, \mathrm{~m}$ & & $1.78, \mathrm{~m}$ & & $1.78, \mathrm{~m}$ & \\
\hline $16 \alpha$ & $1.31, \mathrm{~m}$ & $28.9, \mathrm{CH}_{2}$ & $1.30, \mathrm{~m}$ & $28.9, \mathrm{CH}_{2}$ & $1.31, \mathrm{~m}$ & $28.9, \mathrm{CH}_{2}$ \\
\hline $16 \beta$ & $1.91, \mathrm{~m}$ & & $1.88, \mathrm{~m}$ & & $1.91, \mathrm{~m}$ & \\
\hline $17 \alpha$ & 1.86, ddd $(9.5,8.9,9.0)$ & $48.4, \mathrm{CH}$ & 1.86, ddd $(8.8,8.8,9.0)$ & $48.4, \mathrm{CH}$ & 1.86, ddd $(9.5,8.9,9.0)$ & $48.4, \mathrm{CH}$ \\
\hline 18 & $0.75, \mathrm{~s}$ & $13.2, \mathrm{CH}_{3}$ & $0.76, \mathrm{~s}$ & $13.2, \mathrm{CH}_{3}$ & $0.75, \mathrm{~s}$ & $13.2, \mathrm{CH}_{3}$ \\
\hline 19 & $0.81, \mathrm{~s}$ & $11.2, \mathrm{CH}_{3}$ & $0.81, \mathrm{~s}$ & $11.3, \mathrm{CH}_{3}$ & $0.81, \mathrm{~s}$ & $11.1, \mathrm{CH}_{3}$ \\
\hline 20 & $1.39, \mathrm{~m}$ & $36.8, \mathrm{CH}$ & $1.40, \mathrm{~m}$ & $37.1, \mathrm{CH}$ & $1.40, \mathrm{~m}$ & $36.8, \mathrm{CH}$ \\
\hline 21 & $1.04, \mathrm{~d}(6.6)$ & $18.1, \mathrm{CH}_{3}$ & $1.04, \mathrm{~d}(6.6)$ & $18.1, \mathrm{CH}_{3}$ & $1.04, \mathrm{~d}(6.6)$ & $18.1, \mathrm{CH}_{3}$ \\
\hline $22 \mathrm{a}$ & $1.16, \mathrm{~m}$ & $33.3, \mathrm{CH}_{2}$ & $1.16, \mathrm{~m}$ & $33.3, \mathrm{CH}_{2}$ & $1.16, \mathrm{~m}$ & $33.3, \mathrm{CH}_{2}$ \\
\hline $22 b$ & $1.54, \mathrm{~m}$ & & $1.54, \mathrm{~m}$ & & $1.54, \mathrm{~m}$ & \\
\hline $23 a$ & $1.58, \mathrm{~m}$ & $27.4, \mathrm{CH}_{2}$ & $1.56, \mathrm{~m}$ & $27.4, \mathrm{CH}_{2}$ & $1.56, \mathrm{~m}$ & $27.4, \mathrm{CH}_{2}$ \\
\hline $23 b$ & $1.77, \mathrm{~m}$ & & $1.76, \mathrm{~m}$ & & $1.76, \mathrm{~m}$ & \\
\hline 24 & 3.97, m & $69.8, \mathrm{CH}_{2}$ & $3.96, \mathrm{~m}$ & $69.8, \mathrm{CH}_{2}$ & 3.96, m & $69.8, \mathrm{CH}_{2}$ \\
\hline $1^{\prime}$ & $6.68, \mathrm{~m}$ & $141.8, \mathrm{CH}$ & $\begin{array}{c}6.47, \mathrm{~d}(1.9, \mathrm{Z}) / 7.53 \mathrm{~d} \\
(2.9, E)\end{array}$ & $\begin{array}{c}134.3 \\
(\mathrm{Z}) / 138.8(E) \\
\mathrm{CH}\end{array}$ & $6.75, \mathrm{~m}$ & 137.7, CH \\
\hline $2^{\prime} \mathrm{a}$ & $2.02, \mathrm{~m}$ & $38.1, \mathrm{CH}_{2}$ & & $137.4, \mathrm{C}$ & 1.76, dd $(7.2,1.9)$ & 13.9, $\mathrm{CH}_{3}$ \\
\hline $2^{\prime} \mathrm{b}$ & $2.06, \mathrm{~m}$ & & & & & \\
\hline $3^{\prime}$ & $1.78, \mathrm{~m}$ & $30.0, \mathrm{CH}$ & $7.30, \mathrm{~m}$ & $130.0, \mathrm{CH}$ & & \\
\hline $4^{\prime}$ & $0.95, \mathrm{~d}(7.0)$ * & 23.0, $\mathrm{CH}_{3}$ & $7.24, \mathrm{~m}$ & $129.2, \mathrm{CH}$ & & \\
\hline $5^{\prime}$ & $0.94, \mathrm{~d}(7.0)$ * & 23.0, $\mathrm{CH}_{3}$ & $7.44, \mathrm{~m}$ & $131.6, \mathrm{CH}$ & & \\
\hline
\end{tabular}

* Assignments of these protons may be interchanged.

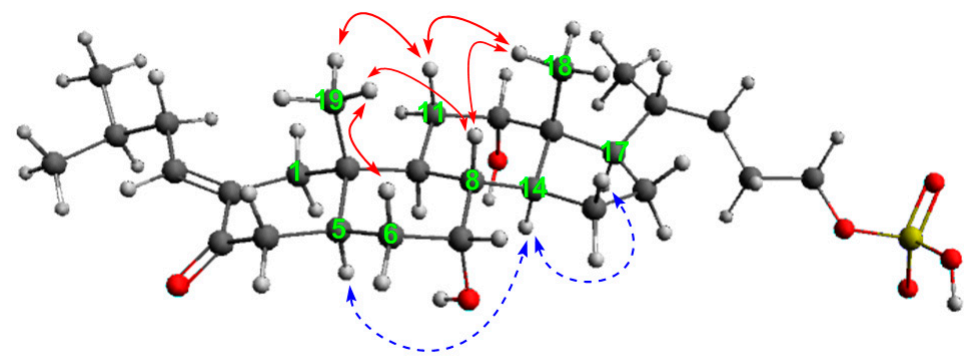

Figure 3. Key NOESY correlations for petromylidene A (1).

Petromylidene B (2) was obtained as a pale-colored oil with a molecular formula $\mathrm{C}_{31} \mathrm{H}_{44} \mathrm{O}_{7} \mathrm{~S}$, as established by HRESIMS (Supplementary Materials Figure S2). The (-)-HRESIMS at $m / z 559.2729$ $[\mathrm{M}-\mathrm{H}]^{-}$matched well with that of the predicted molecular formula, which indicated ten degrees of unsaturation. The ${ }^{1} \mathrm{H}$ NMR and ${ }^{13} \mathrm{C}$ NMR data (Table 1, Supplementary Materials Figures S10 and S11), suggested that 2 also has a 3kPZS (4) skeleton and a substitution on ring A at C-2. Additionally, the ${ }^{1} \mathrm{H}$ and ${ }^{13} \mathrm{C}$ signals of benzyl group were observed, and accounted for the additional four degrees of unsaturation in $\mathbf{2}$, as compared to $\mathbf{1}$. The presence of the benzylidene subsitituent 
on C-2 was supported by the HMBC long range correlations from $\mathrm{H}-1^{\prime}$ to $\mathrm{C}-1$ and $\mathrm{C}-3$, and from $\mathrm{H}-1$ to $\mathrm{C}-1^{\prime}$ (Figure 2). Interestingly, the ${ }^{1} \mathrm{H}$ NMR spectrum displayed two doublets at $\delta_{\mathrm{H}} 6.47(\mathrm{~d}$, $J=1.9) / 7.53(\mathrm{~d}, J=2.9)$, respectively, for the olefinic proton on $\mathrm{C}-\mathrm{1}^{\prime}$. Attempts to isolate the isomers of 2 by choromatographic method were not successful. Compared with similar analogs described previously [14-18], the compound with olefinic proton resonace at $\delta 6.47(\mathrm{~d}, J=1.9)$ could be assigned as $Z$ configuration [14]. Accordingly, the compound with olefinic proton resonance at $\delta 7.53(\mathrm{~d}, J=2.9)$ could be assigned as $E$ configuration [15-18]. The resonance of alkylidene olefinic proton with an $E$ configuration, displayed an approximately $1 \mathrm{ppm}$ downfield shift from that of the $Z$ configuration in both alkylidene and phenylidene substituents. Petromylidene B is a mixture of Z-(2) and E-(2) with approximate ratio of 3:1, as deduced by the integral area in the ${ }^{1} \mathrm{H}$ NMR spectrum. Therefore, the structures of 2 were assigned as 2-(Z)-benzylidene-7 $\alpha, 12 \alpha, 24$-trihydroxy-5 $\alpha$-cholan-3-one-24-sulfate and 2-(E)-benzylidene-7 $\alpha, 12 \alpha, 24$-trihydroxy-5 $\alpha$-cholan-3-one-24-sulfate, trivially named (Z)- and (E)-petromylidene $B$, respectively.

Petromylidene C (3) was obtained as a pale-colored oil with $[\alpha]_{\mathrm{D}}^{25}-22.8$ (c 0.10, MeOH). Its molecular formula, $\mathrm{C}_{26} \mathrm{H}_{42} \mathrm{O}_{7} \mathrm{~S}$ with $\mathrm{m} / z$ 497.2553 [M-H] $]^{-}$(Supplementary Materials Figure S3), indicated six degrees of unsaturation. Its ${ }^{1} \mathrm{H}$ NMR and ${ }^{13} \mathrm{C}$ NMR data (Table 1, Supplementary Materials Figures S16 and S17) were similar to those of $\mathbf{1}$ and 2. The 3kPZS (4), as well as the steroidal scaffold and the hydroxyl stereochemistry, was assigned using the strategies described for $\mathrm{HMBC}$ correlations from $\mathrm{H}-1^{\prime}$ to $\mathrm{C}-1$ and $\mathrm{C}-3$, and from $\mathrm{H}-1$ to $\mathrm{C}-\mathrm{1}^{\prime}$. The comparison of the olefinic proton resonance of 3 with those of $(E)$-2-ethylidenecyclohexanone [11], supported the $E$ configuration for the double bond between $\mathrm{C}-2$ and $\mathrm{C}-1^{\prime}$. The 3 exists only as $2 \mathrm{E}$ isomer, since no proton resonance was observed around $\delta_{\mathrm{H}} 5.80 \mathrm{ppm}$. Therefore, 3 was assigned as 2-(E)-ethylidene-7 $\alpha, 12 \alpha, 24$-trihydroxy-5 $\alpha$-cholan-3-one-24-sulfate and was trivially named petromylidene $C$.

Petromylidenes A-C (1-3) were all potent odorants, which stimulated the adult sea lamprey olfactory epithelium in the electro-olfactogram (EOG) assays. In the EOG recordings, 2 was the most potent and elicited larger responses than the other compounds across a range of concentrations $\left(10^{-10} \mathrm{M}\right.$ to $10^{-6} \mathrm{M}$ ), followed by $\mathbf{1}$, and then 3 (Figure 4 ). The olfactory potencies of $\mathbf{1}-\mathbf{3}$ at $10^{-6} \mathrm{M}$, were approximately one third of that of $3 \mathrm{kPZS}$ at $10^{-6} \mathrm{M}$ [19] and were comparable to that of 3,12-diketo-4,6-petromyzonene-24-sulfate (DKPES), a previously described pheromone released by spermiated male sea lampreys, at $10^{-6} \mathrm{M}$ [20]. The threshold of detection-the lowest concentration that elicited an olfactory response greater than the blank water control-for 1 was $10^{-9} \mathrm{M}$ (paired $t$-test, $t=-4.94, d f=6, p=0.001)$, for 2 was $10^{-11} \mathrm{M}(t=-3.53, d f=6, p=0.006)$, and for 3 was less than $10^{-13} \mathrm{M}(t=-2.52, d f=6, p=0.023)$ (Figure 4$)$. The olfactory responses of pheromonal bile acids released by spermiated male sea lamprey, had detection thresholds of $10^{-10} \mathrm{M}$ to $10^{-13} \mathrm{M}[7,20]$. The threshold of detection of $3 \mathrm{kPZS}$ is $10^{-12} \mathrm{M}$ [19].

In a two-choice maze behavioral assay, ovulated female sea lampreys were attracted to $10^{-12}$ $\mathrm{M}$ of 1 (mean index of preference \pm S.E.M.; $0.232 \pm 0.096, n=11)$ and $10^{-12} \mathrm{M}$ of $3(0.488 \pm 0.097$, $\mathrm{n}=7$ ) (Wilcoxon signed-rank test, $p<0.05$; Figure 5 and Table S1), at comparable magnitudes to that of $10^{-12} \mathrm{M}$ of 3kPZS [21]. Ovulated females also appeared to be attracted to $10^{-12} \mathrm{M}$ of $2(0.534 \pm 0.054$, $\mathrm{n}=3, p=0.250$; Figure 5 and Supplementary Materials Table S1). However, a larger sample size was not possible due to the limited quantity of 2 available for the behavioral assays. 


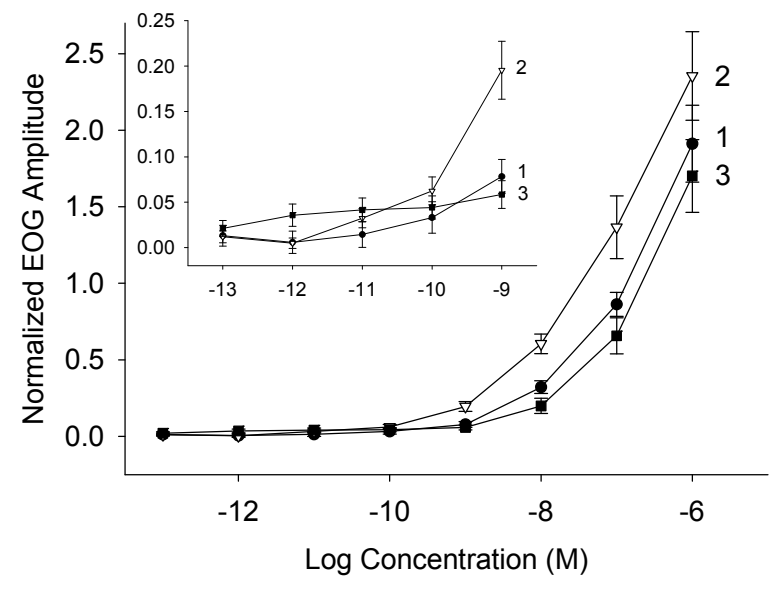

Figure 4. Semi-logarithmic plot of electro-olfactogram (EOG) concentration response curves show 1-3 (petromylidenes A-C, respectively) are stimulatory to the adult sea lamprey olfactory epithelium and have low detection thresholds. The numbers on the right of the figure correspond to each compound (filled circle 1; open triangle 2; filled square 3). Data are presented as the mean normalized EOG amplitude $(n=7)$. Vertical bars represent one standard error of the mean. Insert: Expanded view of responses showing response threshold concentrations.

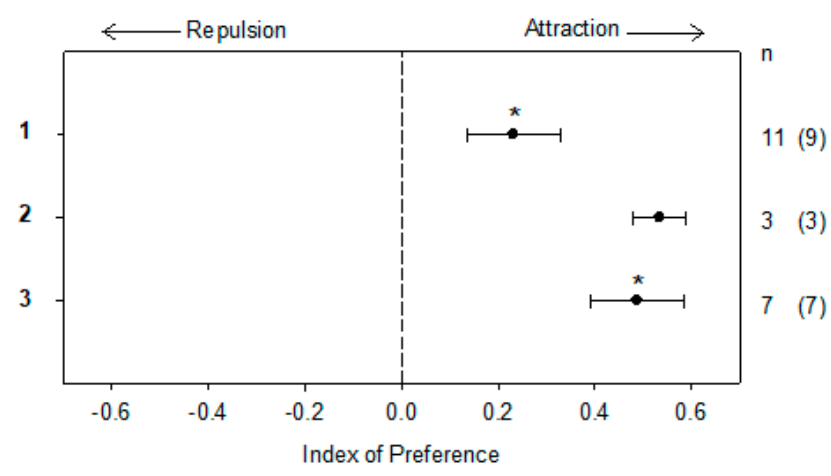

Figure 5. Ovulated female sea lampreys were attracted to petromylidene A (1) and petromylidene C (3) in the two-choice maze $(p<0.05)$. The time the lamprey spent in the treatment or vehicle channel of the maze before and after odorant exposure, was used to calculate an index of preference (see Equation (2) in Section 3). A positive index value indicates attraction and a negative index value indicates repulsion. Data are presented as the mean \pm S.E.M. and evaluated using a Wilcoxon signed-rank test. $n$, sample size, with the number in the parentheses indicating the number of test subjects spending more time in the treatment side.

\section{Experimental Section}

\subsection{General Experimental Procedures}

ESIMS and HRESIMS spectra were measured using a TQ-S TOF LC mass spectrometer (Waters Corporation, Milford, MA, USA). 1D- and 2D-NMR spectra were recorded on an Agilent $900 \mathrm{MHz}$ spectrometer. Column chromatography was performed on silica gel (70-230 and 230-400 mesh, Merck, Darmstadt, Germany) and Sephadex LH-20 (Merck). Semi-preparative HPLC (Waters 1525 binary HPLC pump, 2996 photodiode array detector, and fraction collector III) was performed with a Luna $\mathrm{RP}-18$ column $\left(250 \times 10 \mathrm{~mm}\right.$ i.d.; $5 \mu \mathrm{m}$; Phenomenex), eluted with methanol and $\mathrm{H}_{2} \mathrm{O}$ with a flow rate of $3.0 \mathrm{~mL} / \mathrm{min}$ at room temperature. A gradient of methanol in $\mathrm{H}_{2} \mathrm{O}$ from 30 to $100 \%$ over $30 \mathrm{~min}$ was used. Pre-coated silica gel GF254 plates (Merck) were used for TLC. Spots were first visualized under 
UV light at $254 \mathrm{~nm}$, and then stained by spraying with an acidic methanol solution of $5 \%$ anisaldehyde (Sigma-Aldrich, St. Louis, MO, USA), and heated on a hot plate.

\subsection{Animal Materials}

All experimental procedures involving sea lampreys were approved by the Michigan State University Institutional Animal Use and Care Committee (IACUC) (Animal usage form number: 03/14-054-00). Adult sea lampreys were captured in tributaries of the Laurentian Great Lakes by the U.S. Fish and Wildlife Service and Fisheries and Oceans Canada, according to approved scientific collection permits from those government agencies, transported to the U.S. Geological Survey Hammond Bay Biological Station, Millersburg, Michigan, USA, and held in 500-1000 L aerated tanks supplied with Lake Huron water at $15-19{ }^{\circ} \mathrm{C}$. Adult sea lampreys used for EOG recordings were transported to the University Research Containment Facility at Michigan State University, East Lansing, Michigan, USA, and were held in flow-through tanks (250 L) supplied with aerated, chilled well water, maintained at $7-9{ }^{\circ} \mathrm{C}$.

To produce ovulated females as test subjects for the behavioral assays conducted in June and July 2016, immature female sea lampreys were transferred to acclimation cages constructed of polyurethane mesh and PVC pipe $\left(0.5 \mathrm{~m}^{3}\right)$, located in the lower Ocqueoc River, Millersburg, Michigan to allow natural maturation. Sea lampreys were monitored daily for signs of sexual maturation, including secondary sexual characteristics and expression of ovulated oocytes from the cloacal aperture, following gentle pressure to the abdomen.

\subsection{Extraction and Isolation}

The extraction method used in this study is an adaptation of a previously reported method, developed and optimized, for sea lamprey conditioned water [20,22]. Briefly, spawning phase male sea lamprey (15-30 animals) were placed in a tank and supplied with $50 \mathrm{~L}$ of aerated Lake Huron water maintained at $16-18{ }^{\circ} \mathrm{C}$. The extraction of conditioned water was performed by solid phase extraction, i.e., passed through a bed of $2 \mathrm{~kg}$ of Amberlite XAD $7 \mathrm{HP}$ resin, contained in a series of four 2.5 L-capacity glass columns (Ace Glass Inc., Vineland, NJ, USA). Load speeds were maintained between $400-600 \mathrm{~mL} \cdot 6 \mathrm{~min}^{-1}$. Natural products were eluted with $10 \mathrm{~L}$ of methanol, followed immediately by $5 \mathrm{~L}$ of acetone. During June and July 2014, ten batches of the male-conditioned water was extracted. The solvent from each batch was removed under reduced pressure at $40{ }^{\circ} \mathrm{C}$ by rotoevaporation (Büchi RotovaporH, Flawil, Switzerland) and combined. The water residue was concentrated by lyophilization (Labconco Corporation, KS, USA). The extracts were suspended in methanol and filtered. Filtrates were collected and concentrated under reduced pressure at $40{ }^{\circ} \mathrm{C}$ by rotoevaporation and produced $2.1 \mathrm{~g}$ of extract.

\subsection{Purification of Petromylidene A-C (1-3) and $3 k P Z S$ (4)}

The extract was subjected to liquid chromatography over silica gel (150 g; gradient elution from $95 \% \mathrm{CHCl}_{3} / \mathrm{MeOH}$ to $100 \% \mathrm{MeOH}$, ca. $2.5 \mathrm{~L}$ total volume). Eluents were pooled into 20 fractions, as guided by thin layer chromatography (TLC) analysis. Fraction 14 was concentrated to a residue (ca. $41 \mathrm{mg}$ ), which was further purified using Sephadex $\mathrm{LH}-20$, first on a $\mathrm{CHCl}_{3}-\mathrm{MeOH}$ (1:1) column, and then on a $\mathrm{MeOH}(100 \%)$ column to yield $\mathbf{1}(3.61 \mathrm{mg}), 2(0.10 \mathrm{mg}), \mathbf{3}(1.13 \mathrm{mg})$, and $4(8.86 \mathrm{mg})$.

petromylidene A (1): pale oil; $[\alpha]_{\mathrm{D}}^{25}+6.6(c 0.10, \mathrm{MeOH}),{ }^{1} \mathrm{H}$ and ${ }^{13} \mathrm{C}$ NMR data, see Table 1; HRESIMS $m / z 539.3058$ (calcd for $\mathrm{C}_{29} \mathrm{H}_{47} \mathrm{O}_{7} \mathrm{~S}, 539.3048[\mathrm{M}-\mathrm{H}]^{-}$).

petromylidene B (2): pale oil; ${ }^{1} \mathrm{H}$ and ${ }^{13} \mathrm{C}$ NMR data, see Table 1; HRESIMS $m / z 559.2729$ (calcd for $\mathrm{C}_{31} \mathrm{H}_{43} \mathrm{O}_{7} \mathrm{~S}$, $559.2735[\mathrm{M}-\mathrm{H}]^{-}$).

petromylidene $C$ (3): pale oil; $[\alpha]_{\mathrm{D}}^{25}-22.8($ c $0.10, \mathrm{MeOH}),{ }^{1} \mathrm{H}$ and ${ }^{13} \mathrm{C}$ NMR data, see Table 1; HRESIMS $m / z 497.2553$ (calcd for $\mathrm{C}_{26} \mathrm{H}_{41} \mathrm{O}_{7} \mathrm{~S}, 497.2578[\mathrm{M}-\mathrm{H}]^{-}$). 


\subsection{Electro-Olfactogram (EOG) Recording}

Electro-olfactogram recordings were conducted following a described procedure in References [20,22], to determine the adult sea lamprey olfactory sensitivity to $\mathbf{1}-\mathbf{3}$. Sea lampreys (243.9 g $\pm 17.0,502.4 \mathrm{~mm} \pm 12.8$; mean \pm S.E.M.) were anesthetized with 3-aminobenzoic acid ethyl ester (MS222; $100 \mathrm{mg} \mathrm{L}^{-1}$; Sigma-Aldrich), immobilized with an intra-muscular injection of gallamine triethiodide (3 mg/ $\mathrm{kg}$ of body weight, in $0.9 \%$ saline; Sigma-Aldrich), and placed in a V-shaped Plexiglas stand. Gills were continuously irrigated with aerated water containing $50 \mathrm{mg} \mathrm{L}^{-1} \mathrm{MS}^{222}$, throughout the experiment. The olfactory lamellae were surgically exposed by removing the skin on the surface of the olfactory capsule. A small capillary tube delivered the stimuli and charcoal filtered water to the olfactory epithelium by gravity flow, to prevent desiccation. The differential EOG response to each test stimulus was recorded using borosilicate electrodes filled with $0.04 \%$ agar in $0.9 \%$ saline, connected to solid state electrodes with $\mathrm{Ag} / \mathrm{AgCl}$ pellets (model ESP-M15N, Warner Instruments LLC, Hamden, CT, USA) in $3 \mathrm{M} \mathrm{KCl}$. The recording electrode was placed between two olfactory lamellae and adjusted to maximize the response to L-arginine standard, whilst minimizing the response to the blank control (charcoal filtered water), and the reference electrode was placed on the external skin near the naris. Electrical signals were then amplified by a NeuroLog system (model NL102, Digitimer Ltd., Hertfordshire, England, UK), filtered with a low-pass $60 \mathrm{~Hz}$ filter (model NL125, Digitimer Ltd.), digitized by Digidata 1440A (Molecular Devices LLC, Sunnyvale, CA, USA), and recorded on a PC running AxoScope 10.4 software (Molecular Devices LLC). EOG recordings were conducted in April and May 2016.

For the concentration-response recordings, the olfactory epithelia of sea lampreys were exposed to $10^{-13} \mathrm{M}$ to $10^{-6} \mathrm{M}$ solutions of purified petromylidenes $\mathrm{A}-\mathrm{C}(\mathbf{1}-3) .10^{-3} \mathrm{M}$ stock solutions (in $50 \%$ $\mathrm{MeOH}$ : deionized water) were prepared for each compound, stored at $-20{ }^{\circ} \mathrm{C}$, and then serially diluted with charcoal filtered water to yield $10^{-13} \mathrm{M}$ to $10^{-6} \mathrm{M}$ working solutions. A $10^{-2} \mathrm{M}$ stock solution of L-arginine (in deionized water) was prepared, stored at $4{ }^{\circ} \mathrm{C}$, and then diluted with charcoal filtered water to yield a $10^{-5} \mathrm{M}$ working solution. A $10^{-5} \mathrm{M}$ L-arginine standard was introduced to the olfactory epithelium for $4 \mathrm{~s}$, and the olfactory response was recorded as a reference. Then, the olfactory epithelium was flushed with charcoal filtered water for $2 \mathrm{~min}$. Subsequently, the blank control (charcoal filtered water) was introduced to the olfactory epithelium and recorded to confirm the absence of a response in the charcoal filtered water supply. Next, increasing concentrations of the test stimulus, starting at $10^{-13} \mathrm{M}$ to $10^{-6} \mathrm{M}$, was applied to the olfactory epithelium, recorded, and flushed. Blank control and $10^{-5} \mathrm{M}$ L-arginine standard was measured after every two concentrations. The EOG response magnitudes were measured in millivolts, normalized relative to that of $10^{-5} \mathrm{M} \mathrm{L}$-arginine $(2.892 \pm 0.061$; absolute raw value mean \pm S.E.M.), and blank-corrected $(0.131 \pm 0.005$; absolute raw value mean \pm S.E.M.) as defined in Equation (1):

$$
\text { Normalized EOG Amplitude }=\frac{\mathrm{Rt}-\mathrm{Rb}}{\mathrm{Ra}-\mathrm{Rb}}
$$

where $\mathrm{Rt}$ is the response magnitude to the test stimulus, $\mathrm{Rb}$ is the response magnitude to the blank, and $\mathrm{Ra}$ is the response magnitude to L-arginine at $10^{-5} \mathrm{M}$. The L-arginine standard and blank control responses were comparable to previous studies $[7,20,23]$. The detection threshold was defined as the lowest concentration, where the test stimulus elicited a larger response than the blank control (paired $t$-test, one tailed).

\subsection{Behavioral Assay}

The behavioral responses of ovulated female sea lampreys to purified petromylidenes A-C (1-3) at $10^{-12} \mathrm{M}$ were evaluated using a two-choice maze, previously described (Supplementary Materials Figure S22) in Reference [24]. A single lamprey was placed in a release cage at the furthest point downstream in the maze. After 5 min of acclimation in the cage, the lamprey was released and the 
cumulative amount of time the lamprey spent in each channel was recorded. This time period before odorant application, was used to assess side bias. After $10 \mathrm{~min}$ of recording, the test stimulus was introduced to a random channel and 50\% methanol control (MeOH: deionized water) was introduced to the other channel using peristaltic pumps, at constant rates of $200 \pm 5 \mathrm{~mL} \mathrm{~min}^{-1}$ (Masterflex 07557-00, Cole-Parmer, Vernon Hills, IL, USA). The odorants were pumped into the maze for 5 min without recording the lamprey's behavior. After the $5 \mathrm{~min}$ period, the behavior was recorded for an additional $10 \mathrm{~min}$, whilst odorants were continuously administered. The maze was flushed with water for $10 \mathrm{~min}$, before the start of the next experiment. A 10-min flushing period was deemed to be sufficient time in previous experiments [9] and was confirmed with a rhodamine dye test.

An index of preference was calculated for each trial as defined in Equation (2):

$$
\text { Index of preference }=\frac{A e}{(A e+B e)}-\frac{A c}{(A c+B c)}
$$

where $\mathrm{Bc}$ is the time spent by the test animal in the control channel before odorant application, Be is the time spent in the experimental channel before odorant application, Ac is the time spent in the control channel after odorant application, and Ae is the time spent in the experimental channel after odorant application. The index results in a single number, which can be either positive or negative. The indices of preference were evaluated using a Wilcoxon signed-rank test $(\alpha=0.05)$, to determine if the index of preference was significantly different from zero. A significant positive value of the index of preference, indicated attraction. A significant negative value of the index of preference, indicated repulsion. A non-significant value of the index of preference, indicated neutral. For the statistical analysis, each animal tested was considered to be one independent data point. The trial was discarded if the sea lamprey failed to enter the control and experimental channel for at least $10 \mathrm{~s}$ during the $10 \mathrm{~min}$ period before the odorant was applied, as this was an indication of strong side bias.

\section{Conclusions}

Three previously unreported bile salts were identified from water conditioned with sexually mature male sea lampreys. Compounds 1-3 are highly similar in their configuration and substitution pattern, including all trans-fused rings, a $5 \alpha-\mathrm{H}$ typical of fully saturated rings, and a sulfated ester on the terminal carbon of the steroidal sidechain. Together with $5 \alpha$-myxinol-3 $\beta, 27$-disulfate found in hagfish [8] and 5 $\alpha$-cyprinol-27-sulfate found in Cypriniformes [6], 1-3 highlight the unique structural diversity of the $5 \alpha$ bile salt family. The alkylidene substituents have the $E$ configuration for $\mathbf{1}$ and 3. The benzylidene substituent exists in both $E$ and $Z$ configurations for 2 . The $Z$ configuration was preferred, compared to the $E$ configuration $(Z$ to $E$ ratio $=3: 1)$. The oxo and hydroxyl groups preferentially occupied C-3. Notably, 1-3 are potent odorants that elicit attractive behavioral responses in the adult sea lampreys, indicating they possibly function as pheromones. Continued research on 1-3 and all sea lamprey pheromone components may lead to novel tools with which to control the invasive populations, and provide unique insights to the evolution of multi-component pheromones in vertebrates [25].

Supplementary Materials: ${ }^{1} \mathrm{H}$ NMR, ${ }^{13} \mathrm{C}$ NMR, COSY, HSQC, HMBC, and NOESY spectra and HRESIMS data for compounds 1-3 are available online at http:/ / www.mdpi.com/1660-3397/16/9/308/s1.

Author Contributions: Isolation and identification the structures of petromylidenes A-C, K.L.; Bioassays of compounds, A.M.S. and J.J.R.; Sample collection, S.D.F., and T.J.B.; conceiving and coordination, W.L.; Writing-Original Draft Preparation, K.L. and A.M.S.; Writing-Review \& Editing, T.J.B. and W.L.; Funding Acquisition, W.L. and K.L.

Funding: This work was supported by the Great Lakes Fishery Commission to W.L. and K.L.

Acknowledgments: The U.S. Geological Survey Hammond Bay Biological Station provided facilities for holding sea lampreys. The staff of U.S. Fish and Wildlife Service and Fisheries and Oceans Canada collected sea lampreys.

Conflicts of Interest: The authors declare no conflict of interest. 


\section{References}

1. Buchinger, T.J.; Siefkes, M.J.; Zielinski, B.S.; Brant, C.O.; Li, W. Chemical cues and pheromones in the sea lamprey (Petromyzon marinus). Front. Zool. 2015, 12, 32. [CrossRef] [PubMed]

2. Hara, T.J. Olfaction and gustation in fish: An overview. Acta Physiol. Scand. 1994, 152, 207-217. [CrossRef] [PubMed]

3. Buchinger, T.J.; Li, W.; Johnson, N.S. Bile salts as semiochemicals in fish. Chem. Senses 2014, 39, 647-654. [CrossRef] [PubMed]

4. Haslewood, G. Comparative studies of bile salts. Bile salts of the lamprey Petromyzon marinus L. Biochem. J. 1969, 114, 179-184. [CrossRef] [PubMed]

5. Haslewood, G. Bile salt evolution. J. Lipid Res. 1967, 8, 535-550. [PubMed]

6. Hagey, L.R.; Møller, P.R.; Hofmann, A.F.; Krasowski, M.D. Diversity of bile salts in fish and amphibians: Evolution of a complex biochemical pathway. Physiol. Biochem. Zool. 2010, 83, 308. [CrossRef] [PubMed]

7. Li, K.; Scott, A.M.; Riedy, J.J.; Fissette, S.; Middleton, Z.E.; Li, W. Three novel bile alcohols of mature male sea lamprey (Petromyzon marinus) act as chemical cues for conspecifics. J. Chem. Ecol. 2017, 43, 543-549. [CrossRef] [PubMed]

8. Hofmann, A.F.; Hagey, L.R.; Krasowski, M.D. Bile salts of vertebrates: Structural variation and possible evolutionary significance. J. Lipid Res. 2010, 51, 226-246. [CrossRef] [PubMed]

9. Li, W.; Scott, A.P.; Siefkes, M.J.; Yan, H.; Liu, Q.; Yun, S.-S.; Gage, D.A. Bile acid secreted by male sea lamprey that acts as a sex pheromone. Science 2002, 296, 138-141. [CrossRef] [PubMed]

10. Hoye, T.R.; Dvornikovs, V.; Fine, J.M.; Anderson, K.R.; Jeffrey, C.S.; Muddiman, D.C.; Shao, F.; Sorensen, P.W.; Wang, J. Details of the structure determination of the sulfated steroids PSDS and PADS: New components of the sea lamprey (Petromyzon marinus) migratory pheromone. J. Org. Chem. 2007, 72, 7544-7550. [CrossRef] [PubMed]

11. Piers, E.; Morton, H.E.; Chong, J.M. (Trialkylstannyl) copper (I) reagents: Preparation and reaction with $\alpha, \beta$-unsaturated carbonyl systems. Preparation of $\beta$-trialkylstannyl $\alpha, \beta$-unsaturated ketones. Can. J. Chem. 1987, 65, 78-87. [CrossRef]

12. Davis, L.O.; Putri, M.A.; Meyer, C.L.; Durant, C.P. Phosphoric acid mediated tautomerism of imines: Addition of a secondary enamine intermediate to aldehydes. Tetrahedron Lett. 2014, 55, 3100-3103. [CrossRef]

13. Miesen, F.; Van Dongen, J.; Meijer, E. Synthesis and photochemistry of $(2 S, 4 R)$-and $(2 S, 4 R)-1,2,3$, 4-tetrahydro-4-ethyl-1,1,4-trimethyl-3Z-ethylidene-2-naphthalenols. Recl. Travaux Chim. Pays-Bas 1994, 113, 307-317. [CrossRef]

14. Simpson, A.F.; Bodkin, C.D.; Butts, C.P.; Armitage, M.A.; Gallagher, T. Asymmetric reduction of prochiral cycloalkenones. The influence of exocyclic alkene geometry. J. Chem. Soc. Perkin Trans. 1 2000, 3047-3054. [CrossRef]

15. Lu, S.M.; Bolm, C. Highly enantioselective synthesis of optically active ketones by iridium-catalyzed asymmetric hydrogenation. Angew. Chem. 2008, 120, 9052-9055. [CrossRef]

16. Falck, J.; He, A.; Reddy, L.M.; Kundu, A.; Barma, D.K.; Bandyopadhyay, A.; Kamila, S.; Akella, R.; Bejot, R.; Mioskowski, C. Ring expansion/homologation-aldehyde condensation cascade using tert-trihalomethylcarbinols. Org. Lett. 2006, 8, 4645-4647. [CrossRef] [PubMed]

17. Nakhai, A.; Bergman, J. Synthesis of hydrogenated indazole derivatives starting with $\alpha, \beta$-unsaturated ketones and hydrazine derivatives. Tetrahedron 2009, 65, 2298-2306. [CrossRef]

18. Swarts, H.J.; Haaksman, A.A.; Jansen, B.J.; de Groot, A. The synthesis of chiral decalones, (-)-1, 1, 4a-trimethyl-2-decalol and (+)-geosmin from S-(+)-carvone (part 3). Tetrahedron 1992, 48, 5497-5508. [CrossRef]

19. Siefkes, M.; Li, W. Electrophysiological evidence for detection and discrimination of pheromonal bile acids by the olfactory epithelium of female sea lampreys (Petromyzon marinus). J. Comp. Physiol. A 2004, 190, 193-199. [CrossRef] [PubMed]

20. Li, K.; Brant, C.O.; Siefkes, M.J.; Kruckman, H.G.; Li, W. Characterization of a novel bile alcohol sulfate released by sexually mature male sea lamprey (Petromyzon marinus). PLoS ONE 2013, 8, e68157. [CrossRef] [PubMed]

21. Scott, A.M. Characterization and Disruption of Sea Lamprey Sex Pheromone Communication. Ph.D. Thesis, Michigan State University, East Lansing, MI, USA, 2018. 
22. Fine, J.M.; Sisler, S.P.; Vrieze, L.A.; Swink, W.D.; Sorensen, P.W. A practical method for obtaining useful quantities of pheromones from sea lamprey and other fishes for identification and control. J. Great Lakes Res. 2006, 32, 832-838. [CrossRef]

23. Li, K.; Scott, A.M.; Brant, C.O.; Fissette, S.D.; Riedy, J.J.; Hoye, T.R.; Li, W. Bile salt-like dienones having a novel skeleton or a rare substitution pattern function as chemical cues in adult sea lamprey. Org. Lett. 2017, 19, 4444-4447. [CrossRef] [PubMed]

24. Buchinger, T.J.; Wang, H.; Li, W.; Johnson, N.S. Evidence for a receiver bias underlying female preference for a male mating pheromone in sea lamprey. Proc. R. Soc. Lond. B Biol. Sci. 2013, 280, 1771. [CrossRef] [PubMed]

25. Buchinger, T.J.; Li, K.; Huertas, M.; Baker, C.F.; Jia, L.; Hayes, M.C.; Li, W.; Johnson, N.S. Evidence for partial overlap of male olfactory cues in lampreys. J. Exp. Biol. 2017, 220, 497-506. [CrossRef] [PubMed]

C 2018 by the authors. Licensee MDPI, Basel, Switzerland. This article is an open access article distributed under the terms and conditions of the Creative Commons Attribution (CC BY) license (http:/ / creativecommons.org/licenses/by/4.0/). 